\title{
Stereo chain template effect on the synthesis of conjugated $1,1^{\prime}$-di-[p-(X-phenyl)ethenyl]ferrocenes
}

\author{
J. Gonzalo Rodriguez* and Antonio Lafuente \\ Dpto. Quimica Organica, Universidad Autonoma, Cantoblanco, 28049 Madrid, Spain \\ E-mail: gonzalo.rodriguez@uam.es
}

\begin{abstract}
The synthesis of the 1- and 1,1'-phenylethenylferrocenes of controlled stereochemistry exhibiting $\pi$-extended conjugation was satisfactorily carried out by reaction of 1,1 '-ferrocene dicarboxaldehyde with $p$-(X-benzyl)(triphenyl)phosphorane $\left(\mathrm{X}=\mathrm{NO}_{2}, \mathrm{NMe}_{2}\right)$. Moreover, the Wittig reaction of $(E)$ - or (Z)-1'-p-(X-phenyl)ethenyl-1-ferrocenecarboxaldehyde shows a template effect produced by the phenylethenyl chain, which was analysed. Cyclic voltammetry studies of 1- and 1,1'-p-(X-phenyl)ethenylferrocenes exhibit shifts in oxidation potentials which are consistent with the more effective conjugation of the $E$ than $Z$ isomers, and the electron acceptor character of $\mathrm{NO}_{2}$ vs. $\mathrm{NMe}_{2}$ or $\mathrm{CHO}$ vs. $\mathrm{H}$.
\end{abstract}

Keyword: Wittig reaction, vinylferrocene, template effect, isomerization, cyclic voltammetry

\section{Introduction}

The use of organic molecular materials for conductor and nonlinear optics is an area of considerable activity, due to their inherent synthetic flexibility, which permits the design of different molecular properties. ${ }^{1}$

Ferrocene has attracted the interest of many scientists and research groups because of its possible applications in materials science ${ }^{2}$ and asymmetric synthesis. ${ }^{3}$ Compounds containing ferrocene have been of use in electrochemistry and catalyst chemistry, ${ }^{4}$ as molecular sensors, ${ }^{5}$ ferromagnets, ${ }^{6}$ and in nonlinear optics. ${ }^{7}$ It is now well established that molecular structures with differences in the dipole moments of their ground and excited-states have high second-order nonlinearities. ${ }^{8}$ Molecules with $\pi$ donor-acceptor interactions, such as conjugated vinylferrocene, are promising candidates to show these properties. Thus, the vinylferrocene moiety has been used as a $\pi$-electron donor in several compounds, ${ }^{9}$ with high second harmonic generation (SHG) efficiencies. $^{10}$

The synthesis of conjugated ethenyl or ethynylferrocenes has been recently reported. ${ }^{11,12}$ 
Now, we report the synthesis of $(E, E)-1,1^{\prime}$-di( $p$-X-phenyl)ethenylferrocenes with $\pi$-extended conjugation. The different electronic demands of the phenyl substituents can produce a syn or anti configuration of the chains, with a low syn/anti rotational barrier (about $0.8 \mathrm{Kcal}_{\mathrm{mol}}{ }^{-1}$ ). ${ }^{5 \mathrm{k}, 13}$ Structures showing eclipsed syn conformation in 1,1'-diethynylferrocene or $(E, E)-1,1$ '-di( $p$-Xphenyl)ethenylferrocenes have been reported. ${ }^{14}$

\section{Results and Dicussion}

Conjugated 1,1'-disubstituted ethenylferrocenes with $\pi$-extended conjugation can be satisfactorily obtained according to two different Wittig ${ }^{15}$ procedures, Scheme 1. In method $A$, 1,1 -ferrocenedicarboxaldehyde reacts with the appropriate $\mathrm{X}$ - $p$-benzyl(triphenyl)phosphorane in toluene, affording mixtures of $(E, Z),(E, E)$ and $(Z, Z)$-1,1'-di(p-X-phenylethenyl)ferrocene stereoisomers and monosubstituted $(E / Z)-p$-X-phenylethenylferrocenecarboxaldehyde; in method $B$, the synthesis was carried out in two steps, the Wittig reaction between 1'-[2-(1,3-dioxolan)]-1ferrocenecarboxaldehyde (DFC) and the appropriate phosphorane, followed the acid hydrolysis, to isolate the (E/Z)-1'-p-(X-phenyl)ethenyl-1-ferrocenecarboxaldehyde stereoisomer mixture, which after separation, was followed by a new Wittig reaction with the convenient phosphorane to give the (E,Z)-1,1'-di(p-X-phenylethenyl)ferrocene stereoisomer.

Method B is a good synthetic alternative to prepare 1,1'-di( $p$-X-phenyl)ethenylferrocenes with different $\mathrm{X}$ groups, such as $p-\mathrm{NO}_{2}$ and $p-\mathrm{NMe}_{2}$, with opposite electronic effects, that would permit the formation of a charge-transfer complex between the phenyl rings forced into a syn intramolecular conformation or an anti conformation by the same intermolecular association. Hence, the syn/anti ferrocene conformational equilibrium would be achieved by self-chargetransfer complex stabilisation. ${ }^{11 \mathrm{~d}}$

The synthesis of 1,1'-di(p-nitrophenyl)ethenylferrocene (3) was carried out using the Wittig reaction between 1,1'-ferrocenedicarboxaldehyde (FDC) and p-nitrobenzyl(triphenyl)phosphorane (NTP) in toluene (in 1,1.5 excess, method A). (E,Z)-3 was identified as the only disubstituted stereoisomer, as a red solid (46\%). ${ }^{14 a}$

Moreover, from the reaction mixture were also isolated (E)- and (Z)-1'- $p$ (nitrophenyl)ethenyl-1-ferrocenecarboxaldehyde $(E-\mathbf{1}, 24$ and $Z-1,18 \%)$ as a red solid, mp 142$143{ }^{\circ} \mathrm{C}$ and a red oil respectively, Scheme 1.

The (E,E)-1,1'-di( $p$ - $N, N$-dimethylaminophenyl)ethenylferrocene $(E, E-4)$ stereoisomer was isolated from the reaction mixture between FDC and ( $p-N, N$ dimethylaminobenzyl)(triphenyl)phosphorane (DTP) (1,1.5 excess, method A), as a red solid as the only disubstituted product (20\%). Moreover, from the reaction mixture were also isolated $(E)$ - and (Z)-1'-p-(N,N-dimethylaminophenyl)ethenyl-1-ferrocenecarboxaldehyde, $(E-2,46 \%$ and $Z-2,16 \%)$ as a red solid, and a red oil respectively, Scheme 1.

Hence, the isolation and unambiguous ${ }^{1} \mathrm{H}$ NMR identification of the $1,1^{\prime}-\mathrm{di}(p-\mathrm{X}-$ phenyl)ethenylferrocene derivatives obtained from $E-1$ or $Z-1$ with the same $p-X$ group $\left(X=\mathrm{NO}_{2}\right.$ 
or $\left.\mathrm{NMe}_{2}\right)$ and the phosphorane, showed a unique $(E, Z)$ or $(E, E)$ - isomer. The $(Z, Z)$ isomer was never detected. Thus, the stereochemistry of the products obtained from $(E)-\mathbf{1}$ or $(Z)-\mathbf{1}$ and E-2 or Z-2 isomer, seems to play a template role on the reaction of the phosphorane with the formyl group.
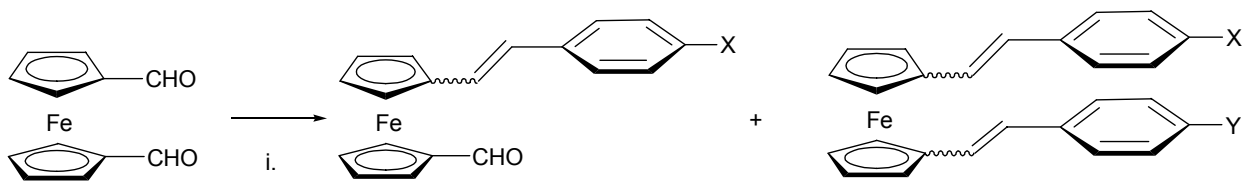

i. $\mathrm{Ph}_{3} \mathrm{P}=\mathrm{CHPh}^{-} p^{-} \mathrm{X}$ ii. $\mathrm{H}_{2} \mathrm{O}, \mathrm{H}^{+}$

$\mathrm{X}=\mathrm{NO}_{2},(E)-\mathbf{1},(Z)-\mathbf{1}$ $\mathrm{X}=\mathrm{NMe}_{2},(E)-2,(Z)-2$

$\mathrm{X}=\mathrm{Y}=\mathrm{NO}_{2},(E, Z)-3$

$\mathrm{X}=\mathrm{Y}=\mathrm{NMe}_{2},(E, E)-4$

$\mathrm{X}=\mathrm{NO}_{2}, \mathrm{Y}=\mathrm{NMe}_{2},(Z, E)-\mathbf{5},(E, E)-5$
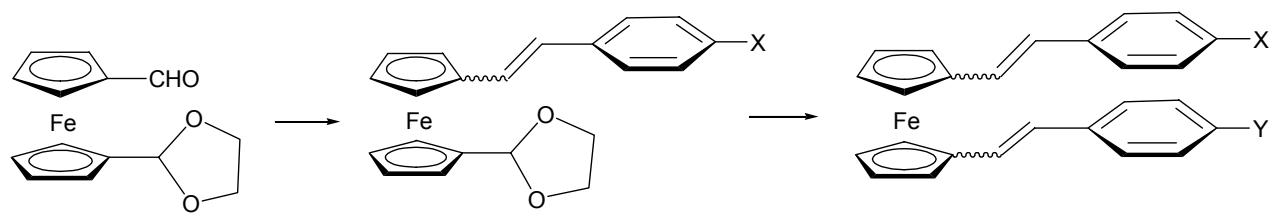

Scheme 1. Wittig reaction with $p$-(X-benzyl)(triphenyl)phosphonium bromide, $\mathrm{KO}^{\mathrm{t}} \mathrm{Bu}$.

In this way, method $B$ was used to explore the influence of the $(E)$ or $(Z)$ stereochemistry of the $p$-X-phenylethenyl chain on the stereochemistry of the 1,1'-disubstituted reaction products. Preparation of $(E / Z)-1,{ }^{14 a, 14 b}$ and $(E / Z)-2$ pure isomers was carried out by reaction of DFC and the corresponding phosphorane, followed by acid hydrolysis.

Thus, following the Method B, compound 3 was obtained by the Wittig reaction between E-1 or Z-1 and NTP.

A mixture of (E)-1 and (Z)-1 isomers was obtained by reaction between DFC and NTP in toluene, after acid hydrolysis, in a $E / Z 3,2$ molar ratio, and in good yield (76\%). The $E-\mathbf{1}$ and Z-1 isomers were isolated pure by crystallization from hexane, Scheme 1.

Compound (E,Z)-3 was obtained as the unique isomer by reaction between (Z)-1 and NTP in dry toluene, as a red solid in good yield (62\%). Wittig reaction in dry tetrahydrofuran instead toluene also gave the $(E, Z)$ isomer as the main product $(65 \%)$ but the $(Z, Z)$ isomer was also isolated in very low yield (EZ/ZZ, 15,1, by NMR). The synthesis and structure of the $(E, Z)-3$ was recently reported, ${ }^{14 \mathrm{~b}}$ Table 1.

Compound $(E, Z)-\mathbf{3}$ was also obtained as the unique isomer, by reaction between $(E)-\mathbf{1}$ and NTP in dry toluene, in 74\% yield. Hence, both monosubstituted $Z-1$ or $E$-1 isomers always yield the disubstituted $(E, Z)-3$ isomer, although the reaction can be slightly influenced by the solvent. $^{14 a}$ In the same way, 1,1'-di( $p-N, N$-dimethylaminophenyl)ethenylferrocene (4) was obtained by method $B$, from $(E)-\mathbf{2}$ or $(Z)-2$ isomers and the appropriate phosphorane. The mixture of $(E / Z)-2$ was obtained by reaction between DFC and DTP in toluene, after acid hydrolysis, as a mixture of the (E/Z)-2 isomers in a 3,1 molar ratio (by ${ }^{1} \mathrm{H} N M R$ ), with an 
excellent yield (89\%). The $E$-2 isomer was isolated pure by crystallization from hexane, while $Z$ 2 remained in solution, Scheme 1. Thus, $(E, E)-\mathbf{4}$ was obtained by Wittig reaction between $(Z)-2$ and DTP in dry toluene, as a red solid, which was unambiguously identified as the only stereoisomer, in 75\% yield. The same isomer $(E, E)-\mathbf{4}$ was also obtained by Wittig reaction between $(E)-2$ and DTP in dry toluene, as the unique isomer, in 78\% yield.

Table 1. Synthesis of $(E, Z)$ - and $(E, E)-1,1^{\prime}-\operatorname{di}(p-X$-phenyl)ethenylferrocenes

\begin{tabular}{ccccc}
\hline & Monosubstituted & & Disubstituted & Yield (\%) \\
\hline Method A & $(Z)-\mathbf{1}$ & $\rightarrow$ & $(E, Z)-\mathbf{3}$ & 62 \\
& $(E)-\mathbf{1}$ & $\rightarrow$ & $(E, Z)-\mathbf{3}$ & 74 \\
& $(Z)-\mathbf{2}$ & $\rightarrow$ & $(E, E)-\mathbf{4}$ & 75 \\
Method B & $(E)-\mathbf{2}$ & $\rightarrow$ & $(E, E)-\mathbf{4}$ & 78 \\
& $(Z)-\mathbf{1}$ & $\rightarrow$ & $(E, Z)-\mathbf{5}$ & 69 \\
& $(E)-\mathbf{1}$ & $\rightarrow$ & $(E, E)-\mathbf{5}$ & 71 \\
& $(Z)-\mathbf{2}$ & $\rightarrow$ & $(E, E)-\mathbf{5}$ & 76 \\
& $(E)-\mathbf{2}$ & $\rightarrow$ & $(E, E)-\mathbf{5}$ & 84 \\
\hline
\end{tabular}

Thus, the Wittig reaction between $E-2$ or $Z-2$ isomers and DTP always yields the $(E, E)-4$ isomer. Hence, during the Wittig reaction there must be an isomerization of $Z$ to $E$ in order to give $(E, E)-\mathbf{4}$ as the only product. Compound $\mathbf{5}$, having two different 1,1' chains, was obtained by reaction between Z-1 and DTP in dry toluene, as a red oil, which was identified as the unique isomer $(Z, E)-5$ in $69 \%$ yield. Hence, the stereochemistry of the (Z)-p-(nitrophenyl)ethenyl moiety was maintained throughout the reaction in the $(Z, E)-5$ product. However, $(E, E)-5$ isomer was obtained by reaction between the $(E)-\mathbf{1}$ isomer and DTP in dry toluene, as a red solid, as the unique isomer, in 71\% yield. The same $(E, E)-5$ isomer was also obtained by Wittig reaction between Z-2 and NTP in toluene, as a red solid, in 76\% yield and the same $(E, E)-5$ isomer was also obtained by Wittig reaction between $E-2$ and NTP in toluene, in $84 \%$ yield, Table 1 .

Hence, whatever the stereochemistry of the starting material, $(E)-\mathbf{2}$ or $(Z)-\mathbf{2}$, the $(E, E)-\mathbf{5}$ product was obtained as the only isomer. Thus, during the Wittig reaction the starting $Z$ isomer completely transforms to the $E$ geometry.

In summary, the reaction of FDC and the corresponding phosphorane takes place through the 1 '- $p$-X-phenylethenylferrocenecarboxaldehyde. The first 1- $p$-X-phenylethenyl chain induces a template effect on the stereochemistry of the second $p$-X-phenylethenyl chain during the Wittig reaction, Table 1. Moreover, the $\mathrm{NO}_{2}$ and $\mathrm{NMe}_{2}$ functional groups, with opposite electronic character, show different behaviour. The electron releasing character of the $p-N, N-$ dimethylaminophenyl substituent produces a decrease in the double bond energy allowing the $Z$ $\rightarrow E$ isomerization, while the resonance of the withdrawing electronic effect of the $p$-nitrophenyl group, does not influence the double bond isomerization. On the other hand, $(Z, E)$ and $(Z, Z)$ 
isomers can be entirely transformed into the $(E, E)$ stereoisomer by prolonged sunlight exposure in solution of ethanol. ${ }^{11 d, 12 a}$

\section{Cyclic Voltammetry}

Electrochemical data for the ferrocenes 1-5 are summarised in Table 2. The peak to peak separations $\left(\Delta E_{\mathrm{p}}=E_{\mathrm{pc}}-E_{\mathrm{pa}}\right)$ are, however, significantly greater than the ideal value of $56.5 \mathrm{mV}$ at $25{ }^{\circ} \mathrm{C}$ for a fully reversible one-electron process, probably due to a combination of uncompensated solution resistance and slightly slow electron-transfer kinetics. ${ }^{2 \mathrm{~d}}$ However, this difference is similar to that measured for ferrocene under comparable experimental conditions.

Processes attributable to the $[\mathrm{m}]^{+} /[\mathrm{m}]$ couple, as reversible as the ferrocenium/ferrocene couple under the same conditions, were observed for all the ferrocenyl compounds studied. The voltammogram of compound $(E, E)-5$ is presented in Figure 1. When compared with the previously reported 4-nitrophenylethenyl or 4-( $N, N$-dimethylamino)phenylethenylferrocenes, the disubstituted ferrocenes show a shift to a more anodic half-wave potential, suggesting that the extra electron-accepting substituent has an important electronic effect on the ferrocenyl fragment. ${ }^{16}$

However, for the ferrocene complexes with analogous stereochemical features, the nitro compounds have a highest oxidation potential than the homologous ( $N, N$-dimethylamino)phenyl derivatives, thus confirming the better electron-accepting nature of the nitro group.

The ferrocene complexes with highest degree of $(E)$ stereochemistry (i.e. $E, E>E, Z$ ) exhibit a lower half-wave potential than those with a higher degree of $(Z)$ stereochemistry. This is in good agreement with the greater stabilisation of the positive charge corresponding to the more effective conjugation of the $(E)$ isomers, and indicates a higher degree of charge transfer from the metal centre to the polyene backbone. ${ }^{17}$

Table 2. Electrochemical data and Hammett constants $\sigma_{\mathrm{p}}$ for ferrocenes 1-5

\begin{tabular}{cccc}
\hline Compound & $\mathrm{E}_{1 / 2}\left(\Delta \mathrm{E}_{\mathrm{p}}\right) / \mathrm{mV}$ & {$[\mathrm{m}]^{+} /[\mathrm{m}]$} & $\sigma_{\mathrm{p}}{ }^{\mathrm{a}}$ \\
\hline$Z-\mathbf{1}$ & $842(83)$ & 331 & 1.20 \\
$E-\mathbf{1}$ & $831(99)$ & 320 & 1.20 \\
$Z-\mathbf{2}$ & $745(135)$ & 234 & -0.41 \\
$E-\mathbf{2}$ & $737(123)$ & 254 & -0.41 \\
$(E, Z)-\mathbf{3}$ & $604(124)$ & 93 & 1.56 \\
$(E, E)-\mathbf{4}$ & $588(133)$ & 77 & -1.76 \\
$(E, E)-5$ & $417(121)$ & -94 & -0.05 \\
& $700(114)$ & 189 & \\
$(E, Z)-5$ & $457(102)$ & -54 & -0.05 \\
& $715(82)$ & 204 & \\
\hline
\end{tabular}

Ferrocene half-wave potential= 511(131) $\mathrm{mV}$. Values taken from Chem. Rev. 1991, 91, 165. 
The aldehydes $\mathbf{1}$ and $\mathbf{2}$ show a higher half-wave potential than ferrocenyl complexes with the 4-nitro- or 4-( $N, N$-dimethylamino)phenylethenyl, probably due to the electron-acceptor character of the aldehyde group. Changing the aldehyde group for the corresponding conjugated chain, such as in 3-5, causes a shift to more cathodic potentials, probably because of the enhanced stabilization of the positive charge of the resultant ferrocenium species at the two conjugated ancillary chains.

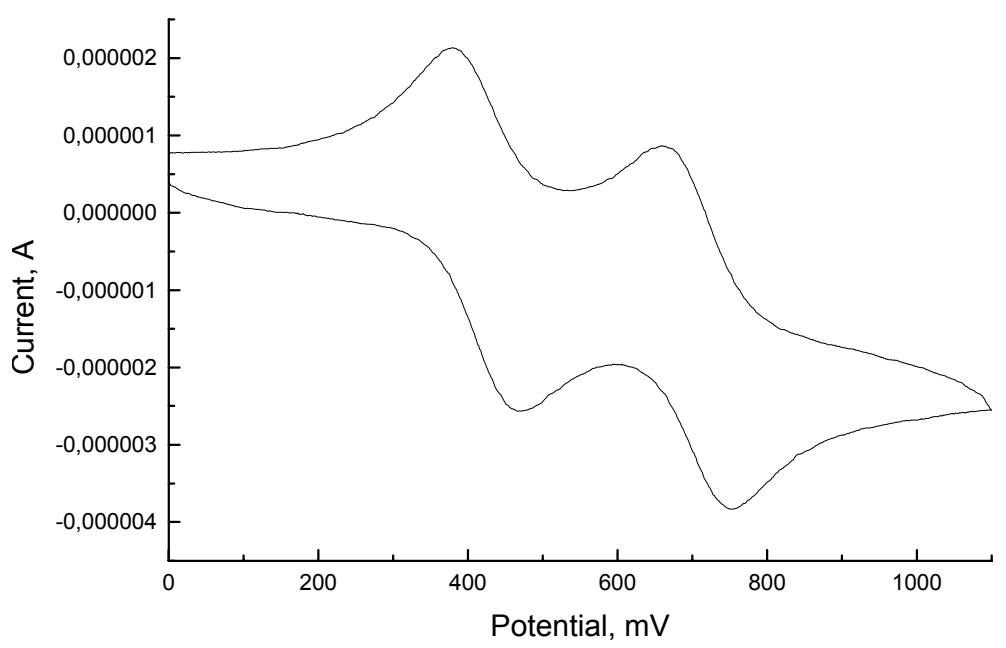

Figure 1. Cyclic voltammetry of compound $(E, E)-\mathbf{5}$, in $\mathrm{CH}_{2} \mathrm{Cl}_{2}$ solution $\left(10^{-2} \mathrm{M}\right)(0.1 \mathrm{M}$ TBAP, working electrode Pt disk $(2 \mathrm{~mm})$ and scan rate $\left.50 \mathrm{mV} \mathrm{s}^{-1}\right)$.

In order to quantify these electronic effects, $E_{1 / 2}$ can be correlated linearly with the summation of the values of the Hammett constant $\left(\sigma_{p}\right)$ for disubstituted ferrocene derivatives, in agreement with the additive nature of the effect of the substituents, Table 2. It is evident that the increase in the electron-withdrawing ability of the substituent, as measured by the Hammett constant, is associated with an increase in the half-wave oxidation potential of the complex, as expected.

\section{Experimental Section}

General Procedures. Melting points were determined in a Reichert hot-stage microscope and are uncorrected. UV-visible spectra were recorded using a Hewlett Packard 8453 spectrophotometer. Infrared spectra were recorded using a Bruker Vector 22 spectrophotometer. NMR spectra were recorded at $300 \mathrm{MHz}$ using a Bruker spectrometer; chemical shifts are given in ppm, using TMS as internal reference $\left({ }^{1} \mathrm{H} /{ }^{1} \mathrm{H}\right.$ was used for structure assignation). Elemental analyses were performed with a LECO CHN-600. Cyclic voltammetry was carried out at room temperature with a conventional three-electrode cell in which the working and auxiliary electrodes were platinum and the reference electrode was $\mathrm{Ag} / \mathrm{AgCl}$ containing $3 \mathrm{M} \mathrm{KCl}$. The 
working electrode consisted of a Pt-disk ultramicroelectrode (with diameter of $2 \mathrm{~mm}$ ), sealed in glass. The supporting electrolyte tetra- $n$-butylammonium perchlorate (TBAP) was used as received. The solvent used in all experiments was dichloromethane of HPLC grade. The measurements were made at a scan rate of $50 \mathrm{mV} / \mathrm{s}$. $E_{1 / 2}$ values were determined as $\left(E_{\mathrm{pa}}+E_{\mathrm{pc}}\right) / 2$, where $E_{\mathrm{pa}}$ and $E_{\mathrm{pc}}$ are the anodic and cathodic peak potentials, respectively. All reported potentials are not corrected for the junction potential.

\section{Synthesis of 1,1'-di(p-X-phenyl)ethenylferrocene (3-4) from 1,1'-ferrocenedicarboxalde- hyde. Method A}

1,1'-Di(p-nitrophenyl)ethenylferrocene (3). In a three necked round-bottom-flask, previously flamed and under argon atmosphere, was placed a suspension of $p$-(nitrobenzyl)(triphenyl)phosphonium bromide $(1 \mathrm{~g}, 2.13 \mathrm{mmol})$ in dry toluene $(15 \mathrm{ml})$ and at $0{ }^{\circ} \mathrm{C}$, potassium tert-butoxide (359 mg, $3.2 \mathrm{mmol}$ ) was added and the mxture stirred for $1 \mathrm{~h}$ and then, a solution of ferrocene-1,1'-dicarboxaldehyde $(345 \mathrm{mg}, 1.42 \mathrm{mmol})$ in dry toluene $(15 \mathrm{ml})$ was slowly added. The residual solid was purified by silica gel column chromatography using hexane/ethyl acetate 2,1 as the eluent, to give (Z)-1, (94 mg, 18\%) as a red oil, $(E)-\mathbf{1},(120 \mathrm{mg}, 24 \%)$ as a red solid, mp $142-143{ }^{\circ} \mathrm{C}$ and $(E, Z)-3$, (316 mg, 46\%), as a red solid, mp $134-137{ }^{\circ} \mathrm{C}$. All spectroscopic data were consistent with those in the literature. ${ }^{14 a}$

1,1'-Di( $p$ - $N, N$-dimethylaminophenyl)ethenyl ferrocene (4). Following method $A$, to a suspension of $p$-( $N, N$-dimethylaminobenzyl)(triphenyl) phosphonium bromide (500 $\mathrm{mg}, 1.07$ $\mathrm{mmol})$ in dry toluene $(10 \mathrm{ml})$, under argon at $0{ }^{\circ} \mathrm{C}$, was added potassium tert-butoxide $(180 \mathrm{mg}$, $1.60 \mathrm{mmol}$ ) and the mixture was stirred for $1 \mathrm{~h}$ and then, a solution of ferrocene-1,1'dicarboxaldehyde $(173 \mathrm{mg}, 0.71 \mathrm{mmol})$ in dry toluene $(5 \mathrm{ml})$ was slowly added. The residual solid was purified by silica gel column chromatography using hexane/ethyl acetate 2,1 as the eluent, to give (Z)-2, (38 mg, 16\%) as a red oil, $(E)-\mathbf{2},(112 \mathrm{mg}, 46 \%)$ as a red solid, mp 156-159 ${ }^{\circ} \mathrm{C}$ and $(E, E)-4,(60 \mathrm{mg}, 20 \%)$, as a red solid, $\mathrm{mp}>310^{\circ} \mathrm{C}$.

Compound (Z)-2. IR (film), 1663 (CHO); 1610 and 1522 (C=C); 1370 (C-N); 1422, 1153 and 1028 (ferrocene); 896 ( $Z$-isomer); 830 ( $p$-subst. ArH). ${ }^{1} \mathrm{H} \mathrm{NMR}\left(\mathrm{CDCl}_{3}\right), \delta 9.86$ (s, $\left.1 \mathrm{H}, \mathrm{CHO}\right)$; $7.18(\mathrm{~d}, 2 \mathrm{H}, J=8.6 \mathrm{~Hz}, \mathrm{H}-2$ and $\mathrm{H}-6 \mathrm{Ph}) ; 6.62$ (d, 2H, $J=8.6 \mathrm{~Hz}, \mathrm{H}-3$ and $\mathrm{H}-5 \mathrm{Ph}) ; 6.43$ (d, 1H, $J=11.8 \mathrm{~Hz},=\mathrm{CHPh}) ; 6.01(\mathrm{~d}, 1 \mathrm{H}, J=11.8 \mathrm{~Hz},=\mathrm{CHCp}) ; 4.70(\mathrm{t}, 2 \mathrm{H}, J=2.2 \mathrm{~Hz}, \mathrm{H}-2$ and H-5 $\mathrm{Cp}_{\mathrm{CHO}}$ ); 4.52 (t, $2 \mathrm{H}, J=2.2 \mathrm{~Hz}, \mathrm{H}-3$ and $\left.\mathrm{H}-4 \mathrm{Cp}_{\mathrm{CHO}}\right) ; 4.35$ (t, $2 \mathrm{H}, J=2.2 \mathrm{~Hz}, \mathrm{H}-2$ and $\mathrm{H}-5 \mathrm{Cp}$ ); $4.25(\mathrm{t}, 2 \mathrm{H}, J=2.2 \mathrm{~Hz}, \mathrm{H}-3$ and $\mathrm{H}-4 \mathrm{Cp}) ; 2.95\left(\mathrm{~s}, 6 \mathrm{H}, \mathrm{NMe}_{2}\right) .{ }^{13} \mathrm{C} \mathrm{NMR}\left(\mathrm{CDCl}_{3}\right), \delta 193.5$ (CHO); 149.5 (C-4, Ph); 129.7 (2C, C-2 and C-6, Ph); 125.5 (C-1, Ph); 122.9 (2C, C=C); 111.9 (2C, C-3 and C-5, Ph); 84.8 and 79.8 (2C, C-1 and C1', Cp); 77.6, 74.5, 70.6 and 69.7 (Cp), 40.4 (2C, $\left.\mathrm{NMe}_{2}\right)$. UV-visible $\left(\mathrm{CH}_{2} \mathrm{Cl}_{2}\right), \lambda_{\max }(\mathrm{nm}), 274(\varepsilon, 19710) ; 325(\varepsilon, 14576) ; 462\left(\varepsilon, 8191 \mathrm{~mol}^{-1}\right.$ $\mathrm{cm}^{-1}$ ). $\mathrm{C}_{21} \mathrm{H}_{21} \mathrm{FeNO}(359.24)$, calcd. C, 70.21; H, 5.89; N, 3.90\% found, C, 70.12; H, 5.69; N, $3.64 \%$.

Compound (E)-2. IR (film), 1659 (CHO); 1606 and 1525 (C=C); 1361 (C-N); 1445, 1169 and 1028 (ferrocene); 950 ( $E$-isomer); 803 (p-subst. ArH). ${ }^{1} \mathrm{H}$ NMR $\left(\mathrm{CDCl}_{3}\right), \delta 9.90$ (s, $\left.1 \mathrm{H}, \mathrm{CHO}\right)$; 7.34 (d, 2H, $J=8.6 \mathrm{~Hz}, \mathrm{H}-2$ and H-6 Ph); 6.71 (d, 2H, $J=8.6 \mathrm{~Hz}, \mathrm{H}-3$ and H-5 Ph); 6.69 (d, 1H, $J$ 
$=16.1 \mathrm{~Hz},=\mathrm{CHPh}) ; 6.53(\mathrm{~d}, 1 \mathrm{H}, J=16.1 \mathrm{~Hz},=\mathrm{CHCp}) ; 4.74(\mathrm{t}, 2 \mathrm{H}, J=2.2 \mathrm{~Hz}, \mathrm{H}-2$ and $\mathrm{H}-5$ $\left.\mathrm{Cp}_{\mathrm{CHO}}\right) ; 4.55$ (t, $2 \mathrm{H}, J=2.2 \mathrm{~Hz}, \mathrm{H}-3$ and $\left.\mathrm{H}-4 \mathrm{Cp}_{\mathrm{CHO}}\right) ; 4.52$ (t, $2 \mathrm{H}, J=2.2 \mathrm{~Hz}, \mathrm{H}-2$ and $\mathrm{H}-5 \mathrm{Cp}$ ); $4.33\left(\mathrm{t}, 2 \mathrm{H}, J=2.2 \mathrm{~Hz}, \mathrm{H}-3\right.$ and H-4 Cp); $2.98\left(\mathrm{~s}, 6 \mathrm{H}, \mathrm{NMe}_{2}\right) .{ }^{13} \mathrm{C} \mathrm{NMR}\left(\mathrm{CDCl}_{3}\right), \delta 193.9(\mathrm{CHO})$; 150.0 (C-4, Ph); 128.3 (=C-Ph); 127.1 (2C, C-2 and C-6, Ph); 125.8 (C-1, Ph); 120.0 (=C-Cp); 112.5 (2C, C-3 and C-5, Ph); 86.8 and 79.7 (2C, C-1 and C1', Cp); 76.6, 74.5, 70.5 and 70.0 (Cp), $40.5\left(2 \mathrm{C}, \mathrm{NMe}_{2}\right)$. UV-visible $\left(\mathrm{CH}_{2} \mathrm{Cl}_{2}\right), \lambda_{\max }(\mathrm{nm}), 272(\varepsilon, 8778) ; 349(\varepsilon, 14230) ; 464(\varepsilon, 848$ $\left.1 \mathrm{~mol}^{-1} \mathrm{~cm}^{-1}\right) . \mathrm{C}_{21} \mathrm{H}_{21} \mathrm{FeNO}(359.24)$, calcd. C, 70.21; H, 5.89; N, 3.90\% found, C, 70.04; H, 5.64; $\mathrm{N}, 4.15 \%$.

Compound (E,E)-4. IR (film), 1609 and $1524(\mathrm{C}=\mathrm{C})$; $1359(\mathrm{C}-\mathrm{N}) ; 1442,1166$ and 1025 (ferrocene); 947 ( $E$-isomer); 806 (p-subst. ArH). ${ }^{1} \mathrm{H}$ NMR $\left(\mathrm{CDCl}_{3}\right), \delta 7.24$ (d, 4H, $J=8.6 \mathrm{~Hz}, 2 \mathrm{x}$ H-2 and H-6 Ph); 6.65 (d, 4H, $J=8.6 \mathrm{~Hz}, 2 \times \mathrm{H}-3$ and $\mathrm{H}-5 \mathrm{Ph}$ ); 6.58 (s, 4H, $2 \times \mathrm{CH}=\mathrm{CH}) ; 4.36$ (s, 4H, 2 x H-2 and H-5 Cp); 4.20 (s, 4H, 2 x H-3 and H-4 Cp); 2.97 (s, 12H, $2 \times \mathrm{NMe}_{2}$ ). ${ }^{13} \mathrm{C}$ NMR $\left(\mathrm{CDCl}_{3}\right), \delta 149.5$ (2C, C-4 Ph); 126.9 (6C, =C-Ph, C-2 and C-6 Ph); 124.8 (2C, C-1 Ph); $121.9(2 \mathrm{C},=\mathrm{C}-\mathrm{Cp}) ; 112.6$ (4C, C-3 and C-5 Ph); 96.1 (2C, C-1 Cp); 69.7 and 67.4 (8C, C-2 and C-3 Cp); $40.6\left(4 \mathrm{C}, \mathrm{NMe}_{2}\right)$. UV-visible $\left(\mathrm{CH}_{2} \mathrm{Cl}_{2}\right), \lambda_{\max }(\mathrm{nm}), 331(\varepsilon, 21971) ; 460\left(\varepsilon, 12821 \mathrm{~mol}^{-1}\right.$ $\mathrm{cm}^{-1}$ ). $\mathrm{C}_{30} \mathrm{H}_{32} \mathrm{FeN}_{2}$ (476.19), calcd. C, 75.63, H, 6.77; N, 5.88\% found, C, 75.72; H, 6.57; N, $5.63 \%$.

\section{Synthesis of 1,1'-di(p-X-phenyl)ethenylferrocene (3-5) from DFC. Method B}

Preparation of $(\mathbf{E} / \mathbf{Z})-1 .{ }^{14 \mathrm{~g}}$ To a suspension of $p$-(nitrobenzyl)(triphenyl)phosphonium bromide, (940 mg, $2.0 \mathrm{mmol})$ in dry toluene $(15 \mathrm{ml})$ at $0{ }^{\circ} \mathrm{C}$, was added potassium tert-butoxide $(336 \mathrm{mg}$, $3.0 \mathrm{mmol}$ ) and the mixture stirred for $30 \mathrm{~min}$. and then, a solution of DFC (380 $\mathrm{mg}, 1.33 \mathrm{mmol})$ in dry toluene $(15 \mathrm{ml})$, was slowly added at $0{ }^{\circ} \mathrm{C}$ under argon. The mixture was stirred at room temperature for $14 \mathrm{~h}$ and after solvent evaporation at reduced pressure, the residual red solid was solved in dichloromethane and washed with an aqueous solution of ammonium chloride and potassium carbonate. The organic layer was dried on $\mathrm{MgSO}_{4}$, filtered and solvent removed at reduced pressure. The residual solid was treated with acetic acid and purified by column chromatography using hexane/ethyl acetate $(2,1)$ as the eluent to give $(Z)-\mathbf{1},(155 \mathrm{mg}, 32 \%)$ as a red oil, $(E)-\mathbf{1},(210 \mathrm{mg}, 44 \%)$ as a red solid, $\mathrm{mp} 142-143^{\circ} \mathrm{C}$.

1,1'-Di(p-nitrophenyl)ethenylferrocene from (Z)-1. To a suspension of $p$ (nitrobenzyl)(triphenyl)phosphonium bromide $(197 \mathrm{mg}, 0.42 \mathrm{mmol})$ in dry toluene $(15 \mathrm{ml})$, under argon atmosphere at $0{ }^{\circ} \mathrm{C}$, was added potassium tert-butoxide $(71 \mathrm{mg}, 0.63 \mathrm{mmol})$. The solution was stirred for $30 \mathrm{~min}$ and then was slowly added a solution of $(Z)-\mathbf{1}$ (150 mg, 0.42 $\mathrm{mmol})$ in dry toluene $(15 \mathrm{ml})$. The mixture was stirred at room temperature overnight and after evaporation of solvent, the residual solid was extracted with dichloromethane and a little water. The organic layer was dried over magnesium sulfate and after filtration and evaporation of solvent, the red solid was crystallized from hexane, to give $(E, Z)-3,(124 \mathrm{mg}, 62 \%)$ as a red solid, $\mathrm{mp} 134-137^{\circ} \mathrm{C}$, and from the hexane solution was recovered the starting $(Z)-\mathbf{1},(40 \mathrm{mg}, 27 \%)$.

1,1'-Di(p-nitrophenyl)ethenylferrocene from (E)-1. To a suspension of $p$ (nitrobenzyl)(triphenyl)phosphonium bromide $(131 \mathrm{mg}, 0.28 \mathrm{mmol})$ in dry toluene $(15 \mathrm{ml})$, was 
added potassium tert-butoxide $(47 \mathrm{mg}, 0.42 \mathrm{mmol})$, and stirred for $30 \mathrm{~min}$. and then $(E)-\mathbf{1}$ was added $(100 \mathrm{mg}, 0.28 \mathrm{mmol})$ in dry toluene $(10 \mathrm{ml})$ give $(E, Z)-3,99 \mathrm{mg},(74 \%)$, as a red solid, $\mathrm{mp}$ $134-137^{\circ} \mathrm{C}$, and the starting $(E)-1$ was recovered, $(12 \mathrm{mg}, 12 \%)$.

A comparable reaction in tetrahydrofuran gave the $(E, Z)$ as the main product $(65 \%)$ but the $(Z, Z)$ isomer was also isolated in very low yield $(<6 \%, E, Z / Z, Z$ in 15,1 molar ratio).

1,1'-Di(p-N,N-dimethylaminophenyl)ethenylferrocene 4 from 2 . Following the method $B$, to a suspension of $p$-(N,N-dimethylaminobenzyl)(triphenyl) phosphonium bromide, (897 mg, 1.92 $\mathrm{mmol})$ in dry toluene $(15 \mathrm{ml})$ at $0{ }^{\circ} \mathrm{C}$, was added potassium tert-butoxide (323 $\left.\mathrm{mg}, 2.88 \mathrm{mmol}\right)$ and stirred for $30 \mathrm{~min}$. and then, was slowly added a solution of 1'-[2-(1,3-dioxolan)]-1ferrocenecarboxaldehyde $(366 \mathrm{mg}, 1.28 \mathrm{mmol})$ in dry toluene $(15 \mathrm{ml})$, at $0{ }^{\circ} \mathrm{C}$ under argon atmosphere. The mixture was stirred at room temperature for $16 \mathrm{~h}$. and after solvent evaporation at reduced pressure, the residual red solid was solved in dichloromethane and washed with an aqueous solution of ammonium chloride and potassium carbonate. The organic layer was dried on $\mathrm{MgSO}_{4}$, filtered and solvent removed at reduced pressure. The residual solid was treated with acetic acid and purified by column chromatography using hexane/ethyl acetate $(2,1)$ as the eluent to give (Z)-2, (101 mg, 22\%) as a red oil, $(E)-2$ and (309 $\mathrm{mg}, 67 \%)$ as a red solid, mp $156-159^{\circ} \mathrm{C}$.

1,1'-Di( $(p-N, N$-dimethylaminophenyl)ethenylferrocene from $(Z)-2$. To a suspension of $p-(N, N-$ dimethylaminobenzyl)(triphenyl)phosphonium bromide (295 $\mathrm{mg}, 0.62 \mathrm{mmol})$ in dry toluene (25 $\mathrm{ml}$ ), under argon atmosphere at $0{ }^{\circ} \mathrm{C}$, was added potassium tert-butoxide (139 $\left.\mathrm{mg}, 1.24 \mathrm{mmol}\right)$. The solution was stirred for $30 \mathrm{~min}$. and then was slowly added a solution of (Z)-2 (110 mg, 0.31 $\mathrm{mmol})$ in dry toluene $(15 \mathrm{ml})$. The mixture was stirred at room temperature overnight and after evaporation of solvent, the residual solid was extracted with dichloromethane and a little amount of water. The organic layer was dried on magnesium sulfate and after filtration and evaporation of solvent, the residual solid was purified by silica gel column chromatography using hexane/ethyl acetate 4,1 as the eluent, to give $(E, E)-\mathbf{4}(109 \mathrm{mg}, 75 \%)$ as a red solid, $\mathrm{mp}>310^{\circ} \mathrm{C}$, and the starting $(Z)-2$ was recovered $(20 \mathrm{mg}, 18 \%)$.

1,1'-Di( $p$ - $\boldsymbol{N}, \boldsymbol{N}$-dimethylaminophenyl)ethenylferrocene from (E)-2. Following above method in ii), $p$-(N,N-dimethylaminobenzyl)(triphenyl)phosphonium bromide $(210 \mathrm{mg}, 0.44 \mathrm{mmol})$ in dry toluene $(15 \mathrm{ml})$, potassium tert-butoxide $(99 \mathrm{mg}, 0.88 \mathrm{mmol})$, and $(E)-2(80 \mathrm{mg}, 0.22 \mathrm{mmol})$ in dry toluene $(5 \mathrm{ml})$ give $(E, E)-4,(83 \mathrm{mg}, 78 \%)$ as a red solid, $\mathrm{mp}>310^{\circ} \mathrm{C}$, and the starting $(E)-2$ was recovered (21 $\mathrm{mg}, 17 \%)$.

1'-p-(Nitrophenyl)ethenyl-1-p-(N,N-dimethylaminophenyl)ethenylferrocene 5 from (Z)-1. To a suspension of $p$-( $N, N$-dimethylaminobenzyl)(triphenyl)phosphonium bromide (80 mg, 0.17 $\mathrm{mmol})$ in dry toluene $(10 \mathrm{ml})$, under argon atmosphere at room temperature, was added potassium tert-butoxide $(30 \mathrm{mg}, 0.26 \mathrm{mmol})$. The solution was stirred for $1 \mathrm{~h}$ and then was slowly added a solution of $(Z)-1(40 \mathrm{mg}, 0.11 \mathrm{mmol})$ in dry toluene $(5 \mathrm{ml})$. The mixture was stirred at room temperature overnight and after evaporation of solvent, the residual solid was partitioned between dichloromethane and water and extracted with dichloromethane. The organic layer was dried on magnesium sulfate and after filtration and evaporation of solvent, the residual 
solid was purified by silica gel column chromatography using hexane/ethyl acetate 3,1 as the eluent, to give $(E, Z)-5$, (37 mg, 69\%) as a red oil. IR (film), 1607 and $1593(\mathrm{C}=\mathrm{C}) ; 1520$ and 1340 $\left(\mathrm{NO}_{2}\right) ; 1377(\mathrm{C}-\mathrm{N}) ; 1107$ and 1030 (ferrocene); 952 (E-isomer); 856 (Z-isomer); 808 (p-subst. ArH). ${ }^{1} \mathrm{H}$ NMR $\left(\mathrm{CDCl}_{3}\right), \delta 8.03\left(\mathrm{~d}, 2 \mathrm{H}, J=8.9 \mathrm{~Hz}, \mathrm{H}-3\right.$ and $\left.\mathrm{H}-5 \mathrm{Ph}_{\mathrm{NO} 2}\right) ; 7.37(\mathrm{~d}, 2 \mathrm{H}, J=8.9 \mathrm{~Hz}$, H-2 and H-6 $\left.\mathrm{Ph}_{\mathrm{NO} 2}\right) ; 7.31$ (d, 2H, $J=8.9 \mathrm{~Hz}, \mathrm{H}-2$ and $\left.\mathrm{H}-6 \mathrm{Ph}_{\mathrm{NMe} 2}\right) ; 6.71$ (d, 2H, $J=8.9 \mathrm{~Hz}, \mathrm{H}-3$ and $\left.\mathrm{H}-5 \mathrm{Ph}_{\mathrm{NMe} 2}\right) ; 6.60(\mathrm{~d}, 1 \mathrm{H}, J=16.2 \mathrm{~Hz},=\mathrm{CHPh}) ; 6.50(\mathrm{~d}, 1 \mathrm{H}, J=16.2 \mathrm{~Hz},=\mathrm{CHCp}) ; 6.43$ (d, $1 \mathrm{H}, J=12.1 \mathrm{~Hz},=\mathrm{CHCp}) ; 6.34(\mathrm{~d}, 1 \mathrm{H}, J=12.1 \mathrm{~Hz},=\mathrm{CHPh}) ; 4.35(\mathrm{t}, 2 \mathrm{H}, J=1.8 \mathrm{~Hz}, \mathrm{H}-2$ and H-5

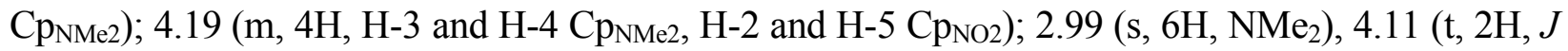
$=1.8 \mathrm{~Hz}, \mathrm{H}-3$ and H-4 Cp $\left.\mathrm{NO}_{\mathrm{NO}}\right)$. UV-visible $\left(\mathrm{CH}_{2} \mathrm{Cl}_{2}\right), \lambda_{\max }(\mathrm{nm}), 332(\varepsilon, 11223) ; 476(\varepsilon, 10251$ $\left.\mathrm{mol}^{-1} \mathrm{~cm}^{-1}\right) . \mathrm{C}_{28} \mathrm{H}_{26} \mathrm{FeN}_{2} \mathrm{O}_{2}$ (478.13), calcd. C, 70.30; H, 5.48; N, 5.86\% found, C, 70.21; H, 5.66; $\mathrm{N}, 5.97 \%$.

1 '-p-(nitrophenyl)ethenyl-1-p-( $N, N$-dimethylaminophenyl)ethenylferrocene 5 from (E)-1. To a suspension of $p$-(N,N-dimethylaminobenzyl)(triphenyl)phosphonium bromide $(98.1 \mathrm{mg}$, $0.21 \mathrm{mmol})$ in dry toluene $(10 \mathrm{ml})$, under argon atmosphere at room temperature, was added potassium tert-butoxide $(36 \mathrm{mg}, 0.32 \mathrm{mmol}$ ). The solution was stirred for $1 \mathrm{~h}$ and then was slowly added a solution of $(E)-1(51 \mathrm{mg}, 0.14 \mathrm{mmol})$ in dry toluene $(5 \mathrm{ml})$. The mixture was stirred at room temperature overnight and after evaporation of solvent, the residual solid was extracted with dichloromethane and a little amount of water. The organic layer was dried on magnesium sulate and after filtration and evaporation of solvent, the residual solid was purified by silica gel column chromatography using hexane/ethyl acetate 3,1 as the eluent, to give $(E, E)$ 5, (49 $\mathrm{mg}, 71 \%$ ) as a red solid, $\mathrm{mp}>250{ }^{\circ} \mathrm{C}$. IR (film), 1607 and $1591(\mathrm{C}=\mathrm{C}) ; 1508$ and 1334 $\left(\mathrm{NO}_{2}\right) ; 1360(\mathrm{C}-\mathrm{N}) ; 1108$ and 1031 (ferrocene); 949 (E-isomer); 809 ( $p$-subst. ArH). ${ }^{1} \mathrm{H}$ NMR $\left(\mathrm{CDCl}_{3}\right), \delta 7.93\left(\mathrm{~d}, 2 \mathrm{H}, J=8.9 \mathrm{~Hz}, \mathrm{H}-3\right.$ and H-5 $\left.\mathrm{Ph}_{\mathrm{NO} 2}\right) ; 7.22(\mathrm{~d}, 2 \mathrm{H}, J=8.9 \mathrm{~Hz}, \mathrm{H}-2$ and H-6 $\left.\mathrm{Ph}_{\mathrm{NO} 2}\right) ; 7.06\left(\mathrm{~d}, 2 \mathrm{H}, J=8.9 \mathrm{~Hz}, \mathrm{H}-2\right.$ and $\left.\mathrm{H}-6 \mathrm{Ph}_{\mathrm{NMe} 2}\right) ; 6.81\left(\mathrm{~d}, 1 \mathrm{H}, J=16.2 \mathrm{~Hz},=\mathrm{CHCp} \mathrm{Ph}_{\mathrm{NO} 2}\right)$; $6.60\left(\mathrm{~d}, 1 \mathrm{H}, J=16.2 \mathrm{~Hz},=\mathrm{CHPh} \mathrm{Ph}_{\mathrm{NO} 2}\right) ; 6.48\left(\mathrm{~d}, 1 \mathrm{H}, J=16.1 \mathrm{~Hz},=\mathrm{CHPh} \mathrm{Ph}_{\mathrm{NMe} 2}\right) ; 6.47(\mathrm{~d}, 2 \mathrm{H}$, $J=8.9 \mathrm{~Hz}, \mathrm{H}-3$ and H-5 $\left.\mathrm{Ph}_{\mathrm{NMe} 2}\right) ; 6.34\left(\mathrm{~d}, 1 \mathrm{H}, J=16.1 \mathrm{~Hz},=\mathrm{CHCp} \mathrm{Ph}_{\mathrm{NMe} 2}\right) ; 4.49$ (t, $2 \mathrm{H}, J=1.8$ $\mathrm{Hz}, \mathrm{H}-2$ and $\left.\mathrm{H}-5 \mathrm{Cp}_{\mathrm{NO} 2}\right) ; 4.43$ (t, 2H, $J=1.8 \mathrm{~Hz}, \mathrm{H}-2$ and $\left.\mathrm{H}-5 \mathrm{Cp}_{\mathrm{NMe} 2}\right) ; 4.34$ (t, 2H, $J=1.8 \mathrm{~Hz}$, $\mathrm{H}-3$ and $\left.\mathrm{H}-4, \mathrm{Cp}_{\mathrm{NO} 2}\right) ; 4.22$ (t, 2H, $J=1.8 \mathrm{~Hz}, \mathrm{H}-3$ and $\left.\mathrm{H}-4, \mathrm{Cp}_{\mathrm{NMe} 2}\right) ; 2.94$ (s, 6H, NMe 2 ). UVvisible $\left(\mathrm{CH}_{2} \mathrm{Cl}_{2}\right), \lambda_{\max }(\mathrm{nm}), 337(\varepsilon, 16128) ; 506\left(\varepsilon, 15061 \mathrm{~mol}^{-1} \mathrm{~cm}^{-1}\right) . \mathrm{C}_{28} \mathrm{H}_{26} \mathrm{FeN}_{2} \mathrm{O}_{2}(478.13)$, calcd. C, 70.30; H, 5.48; N, 5.86\% found, C, 70.18; H, 5.65; N, 5.94\%.

1'-p-(nitrophenyl)ethenyl-1-p-(N,N-dimethylaminophenyl)ethenylferrocene 5 from (Z)-2. To a suspension of $p$-(nitrobenzyl)(triphenyl)phosphonium bromide (122 $\mathrm{mg}, 0.26 \mathrm{mmol}$ ) in dry toluene $(20 \mathrm{ml})$, under argon atmosphere at room temperature, was added potassium tert-butoxide (44 mg, $0.39 \mathrm{mmol}$ ). The solution was stirred for $30 \mathrm{~min}$ and then a solution of $(Z)$ $2(60 \mathrm{mg}, 0.17 \mathrm{mmol})$ in dry toluene $(15 \mathrm{ml})$ was slowly added. The mixture was stirred at room temperature overnight and after evaporation of solvent, the residual solid was extracted with dichloromethane and a little water. The organic layer was dried on magnesium sulfate and after filtration and evaporation of solvent, the residual solid was purified by silica gel column chromatography using hexane/ethyl acetate 3,1 as the eluent, to give $(E, E)-\mathbf{5},(61 \mathrm{mg}, 76 \%)$ as a red solid, $\mathrm{mp}>250^{\circ} \mathrm{C}$. 
1'-p-(nitrophenyl)ethenyl-1-p-(N,N-dimethylaminophenyl)ethenylferrocene 5 from (E)-2. To a suspension of p-(nitrobenzyl)(triphenyl)phosphonium bromide (197 mg, $0.42 \mathrm{mmol}$ ) in dry toluene $(25 \mathrm{ml})$, under argon atmosphere at room temperature, was added potassium tert-butoxide (71 $\mathrm{mg}$, $0.63 \mathrm{mmol}$ ). The solution was stirred for $30 \mathrm{~min}$ and then was slowly added a solution of (E)-2 (100 $\mathrm{mg}, 0.28 \mathrm{mmol})$ in dry toluene $(20 \mathrm{ml})$. The mixture was stirred at room temperature overnight and after evaporation of solvent, the residual solid was partitioned in dichloromethane and water and extracted in chloroform. The organic layer was dried on magnesium sulfate and after filtration and evaporation of solvent, the residual solid was purified by silica gel column chromatography using hexane/ethyl acetate 3,1 as the eluent, to give (E,E)-5, $(112 \mathrm{mg}, 84 \%)$ as a red solid, $\mathrm{mp}>250{ }^{\circ} \mathrm{C}$.

$(\mathbf{Z}, \mathbf{E})-5 \rightarrow$ (E,E)-5 Isomerization. To a solution of (Z,E)-5 (35 mg, $0.074 \mathrm{mmol})$ in ethanol (10 $\mathrm{ml}$ ), iodine (one crystal) was added. The mixture was exposed to the sunlight and stirred for 7 days at $\mathrm{rt}$ (monitoring by thin layer chromatography). The solvent was removed under reduced pressure and the residual solid was solved in dichloromethane and treated with an aqueous solution of sodium thiosulfate. The organic layer was dried on $\mathrm{MgSO}_{4}$, filtered and solvent removed under reduced pressure giving (E,E)-5 as a red solid, m.p. $>250^{\circ} \mathrm{C},(33 \mathrm{mg}, 94 \%)$.

\section{References}

1. (a) Dalton, L. Adv. Polym. Sci. 2002, 158, 1. (b) Arivouli, D. Pramana J. Phys. 2001, 57, 871. (c) Costantino, U. Adv. Sci. Technol. 1999, 15, 479. (d) Axt, V. M.; Mukamel, S. Rev. Mod. Phys. 1998, 70, 145. (e) Choi, K.M.; Shea, K. J. Plastics Engineering 1998, 49, 437. (f) Bloor, D; Chance, R. R. In Polydiacetylenes, NATO ASI series E, $\mathrm{n}^{\mathbf{0}} 102$, Matinus Nijkoff Publishers: Boston 1985. (g) Stiegman, A. E.; Graham, E.; Perry, K. J.; Khundkard, R.; Cheng, L. T.; Perry, J. W. J. Am. Chem. Soc. 1991, 113, 7658 and references cited therein.

2. (a) Delgado, J. L.; de la Cruz, P.; López-Arza, V.; Langa, F. Tetrahedron Lett. 2004, 45, 1651. (b) Meier, H.; Petermann, R. Tetrahedron Lett. 2000, 41, 5475. (c) Togni, A.; Hayashi, T. In Ferrocene-Homogeneous Catalysis, Organic Synthesis and Materials Science, VCH, New York, 1995. (d) Astruc, D. In: Electron Transfer and Radical Processes in Transition-Metal Chemistry, Electrochemistry, VCH, New York 1995 Chap. 2.

3. (a) Roca, F. X.; Motevalli, M.; Richards, C. J. J. Am. Chem. Soc. 2005, 127, 2388. (b) Miniere, S.; Reboul, V.; Metzner, P.; Fochi, M.; Bonini, B. F. Tetrahedron: Asymmetry 2004, 15, 3275. (c) Clarkson, G. J.; Ansell, J. R.; Cole-Hamilton, D. J.; Pogorzelec, P. J.; Whittell, J; Wills, M. Tetrahedron: Asymmetry 2004, 15, 1787. (d) Atkinson, R. C. J.; Gibson, V. C.; Long, N. J. Chem. Soc. Rev. 2004, 33, 313. (e) Naguyen, P; Elipe, P. G.; Manners, I. Chem. Rev. 1999, 99, 1515.

4. (a) Nettekoven, U.; Naud, F.; Schnyder, A.; Blaser, H-U. Synlett 2004, 14, 2549. (b) Torres, J. C.; Pilli, R. A.; Vargas, M. D.; Violante, F. A.; Garden, S. J.; Pinto, A. C. Tetrahedron 2002, 58, 4487 (and references cited therein). 
5. (a) Li, M.; Cai, P.; Duan, Ch.; Lu, F.; Xie. J.; Meng, Q. Inorg. Chem. 2004, 43, 5174. (b) Cui, X.; Carapuca, H. M.; Delgado, R.; Drew, M. G. B.; Felix, V. Dalton Trans. 2004, 11, 1743. (c) Patel, H.; Li, X.; Karan, H. I. Biosens. Bioelectron. 2003, 18, 1073. (d) Bucher, Ch.; Devillers, Ch.; Moutet, J-C.; Royal, G.; Saint-Aman, E. Chem. Commun. 2003, 7, 888. (e) Reynes, O.; Royal, G.; Chainet, E.; Moutet, J-C.; Saint-Aman, E. Electroanalysis 2003, 15, 65. (f) Sutcliffe, O. B.; Chesney, A.; Bryce, M. R. J. Organomet. Chem. 2001, 637-639, 134. (g) Kim, C.; Park, E.; Song, C. K.; Koo, B. W. Synth. Metals 2001, 123, 493. (h) Colbert, M. C. B.; Ingham, S. L.; Lewis, J.; Long, N. J.; Raithby, P. R. J. Chem. Soc., Dalton Trans.1994, 2215. (i) Beer, P. D.; Chen, Z.; Goulden, A. J.; Graydon, A.; Stokes, S. E.; Wear, T. J. Chem. Soc., Chem. Commun.1993, 1834. (j) Chi, K. M.; Calabrese, J. C.; Reiff, W. M.; Miller, J. S. Organometallics 1991, 19, 668. (k) Constable, E. C. Angew. Chem. Int. Ed. 1991, 30, 407.

6. (a) Meng, X.; Hou, H.; Li, G.; Ye, B.; Ge, T.; Fan, Y.; Zhu, Y.; Sakiyama, H. J. Organomet. Chem. 2004, 689, 1218. (b) Sun, Q.; Xu, K.; Peng, H.; Zheng, R.; Haeussler, M.; Tang, B. Z. Macromolecules 2003, 36, 2309. (c) Elsner, O.; Ruiz-Molina, D.; Ratera, I.; VidalGancedo, J.; Rovira, C.; Veciana, J. J. Organomet. Chem. 2001, 637-639, 251. (d) Kulbaba, K.; Resendes, R.; Cheng, A.; Bartole, A.; Safa-Sefat, A.; Coombs, N.; Stover, H. D. H.; Greedan, J. E.; Ozin, G. A.; Manners, I. Adv. Mater. 2001, 13, 732. (e) Miller, J. S.; Epstein, A. J. Angew. Chem. Int. Ed. 1994, 33, 385. (f) Marder, S. R.; Bruce, D. W.; O'Hare, D. In Inorganic Materials, Wiley: Chichester, 1992; p115, and references cited therein. (g) Kollmar, C.; Couty, M.; Kahn, O. J. Am. Chem. Soc. 1991, 113, 7994.

7. (a) Zhang, F.; Vill, V.; Heck, J. Organometallics 2004, 23, 3853. (b) Peris, E. Coord. Chem. Rev. 2004, 248, 279. (c) Huang, G-S.; Liang, Y-M.; Wu, X-L.; Liu, W-M.; Ma, Y-X. Appl. Organomet. Chem. 2003, 17, 706. (d) Shin, D. M.; Lee, I. S.; Chung, Y. K. Eur. J. Inorg. Chem. 2003, 12, 2311. (e) Tsuboya, N.; Hamasaki, R.; Ito, M.; Mitsuishi, M.; Miyashita, T.; Yamamoto, Y. J. Mater. Chem. 2003, 13, 511. (f) Powell, C. E.; Cifuentes, M. P.; Morrall, J. P.; Stranger, R.; Humphrey, M. G.; Samoc, M.; Luther-Davies, B.; Heath, G. A. J. Am. Chem. Soc. 2003, 125, 602. (g) Tsuboya, N.; Lamrani, M.; Hamasaki, R.; Ito, M.; Mitsuishi, M.; Miyashita, T.; Yamamoto, Y. J. Mater. Chem. 2002, 12, 2701. (h) Cai, Y.; Song, Y.; Zheng, H.; Niu, Y.; Du, Ch.; Xin, X. Chem. Lett. 2002, 5, 508. (i) Stankovic, E.; Toma, S.; Van Boxel, R.; Asselberghs, I.; Persoons, A. J. Organomet. Chem. 2001, 637-639, 426. (k) Moore, A. J.; Chesney, A.; Bryce, M. R.; Batsanov, A. S.; Kelly, J. F.; Howard, J. A. K.; Perepichka, I. F.; Perepichka, D. F.; Meshulam, G.; Berkovic, G.; Kotler, Z.; Mazor, R.; Khodorkovsky, V. Eur. J. Org. Chem. 2001, 14, 2671. (1) Davies, D. A.; Silver, J.; Cross, G.; Thomas, P. J. Organomet. Chem. 2001, 631, 59. (m) Mata, J. A.; Peris, E.; Uriel, S.; Llusar, R.; Asselberghs, I.; Persoons, A. Polyhedron 2001, 20, 2083. (n) Hendrickx, E.; Persoons, A.; Samson, S.; Stephenson, G. R. J. Organomet. Chem. 1997, 542, 295. (o) Long, N. J. Angew. Chem. Int. Ed. 1995, 34, 21. (p) Kott, K. L.; Higgins, D. A.; McMahon, R. J.; Corn, R. C. J. Am. Chem. Soc. 1993, 115, 5342. (q) Yuan, Z.; Stringer. G.; Jobe, I. R.; Kreller, D.; Scott, K.; Koch, L.; Taylor, N. J.; Marder, T. B. J. Organomet. Chem. 1993, 
452, 115. (r) Levine, B. F.; Betea, C. C. J. Chem. Phys. 1977, 66, 1070. (s) Oudar, J. L.; Chemla, D. S. J. Chem. Phys. 1977, 66, 2664.

8. (a) Janowska, I.; Zakrzewski, J.; Nakatani, K.; Delaire, J.A.; Palusiak, M.; Walak, M.; Scholl, H. J. Organomet. Chem. 2003, 675, 35. (b) Rojo, G.; Agullo-López, F.; Campo, J. A.; Cano, M.; Lagunas, M. C.; Heras, J. V. Synth. Metals 2001, 124, 201. (c) Mata, J. A.; Peris, E.; Asselberghs, I.; Van Boxel, R.; Persoons, A. New J. Chem. 2001, 25, 1043. (d) Krishnan, A.; Pal, S. K.; Nandakumar, P.; Samuelson, A. G.; Das, P. K. Chem. Phys. 2001, 265, 313. (e) Mata, J. A.; Peris, E.; Asselberghs, I.; Van Boxel, R.; Persoons, A. New J. Chem. 2001, 25, 299. (f) Pal, S. K.; Krishnan, A.; Das, P. K.; Samuelson, A. G. J. Organomet. Chem. 2000, 604, 248. (g) Wong, H.; Meyer-Friedrichsen, T.; Farrell, T.; Mecker, Ch.; Heck, J. Eur. J. Inorg. Chem. 2000, 4, 631.

9. (a) McAdam, C. J.; Morgan, J. L.; Robinson, B. H.; Simpson, J.; Rieger, P. H.; Rieger, A. L. Organometallics 2003, 22, 5126. (b) Nicoud, J. F.; Twieg, R. J.; Chemla, D. S.; Zyss, J. In Nonlinear Optical Properties of Organic Molecules and Crystals, Academic Press: New York, 1987.

10. (a) Pal, S. K.; Krishnan, A; Das. P. K.; Samuelson, A. G. J. Organomet. Chem. 2001, 637639, 827. (b) Tien, H. T.; Salomon, Z.; Liu, W.; Ottoya, A. Anal. Lett. 1993, 26, 819. (c) Albery, W. J.; Mount, A. R. J. Chem. Soc., Faraday Trans. 1993, 89, 327. (d) Toreki, R.; Vaughan, G. A.; Schrock, R. R.; Davis, W. M. J. Am. Chem. Soc. 1993, 115, 127. (e) Balavoine, G. G. A.; Daran, J. C.; Iftime, G.; Lacroix, P. G.; Manoury, E.; Delaire, J. A.; Maltey-Fanton, I.; Nakatani, K.; Di Bella, S. Organometallics 1991, 18, 21. (f) Leddy, J.; Bard, A. J. J. Electroanal. Chem. Interfacial Electrochem. 1985, 189, 203. (g) Schlögl, K.; Egger, H. Monatsh. Chem. 1963, 64, 376.

11. (a) Paolucci, D.; Marcaccio, M.; Bruno, C.; Braga, D.; Polito, M.; Paolucci, F. Organometallics 2005, 24, 1198. (b) Liu, W.; Xu, Q.; Ma, Y.; Liang, Y.; Dong, N.; Guan, D. J. Organomet. Chem. 2001, 625, 128. (c) Mata, J. A.; Uriel, S.; Llusar, R.; Peris, E. Organometallics 2000, 19, 3797. (d) Rodríguez, J. G.; Gayo, M.; Fonseca, I. J. Organomet. Chem. 1997, 534, 35.

12. (a) Rodríguez, J. G.; Pleite, S. J. Organomet. Chem. 2001, 637-639, 230. (b) Fink, H.; Long, N. J.; Martin, A. J.; Opromolla, G.; White, A. J. P.; Williams, D. J.; Zanello, P. Organometallics 1997, 16, 2646. (c) Rodríguez, J. G.; Oñate, A.; Martín-Villamil, R.; Fonseca, I. J. Organomet. Chem. 1996, 513, 71.

13. Luke, W. D.; Streitweiser, A. J. Am. Chem. Soc. 1981, 103, 3241.

14. (a) Chiffre, J.; Averseng, F.; Balavoine, G. G. A.; Daran, J. C.; Iftime, G.; Lacroix, P. G.; Manoury, E.; Nakatani K. Eur. J. Inorg. Chem. 2001, 9, 2221. (b) Mata, J. A.; Peris E, Llusar, R.; Uriel S, Cifuentes, M. P.; Humphrey, M. G.; Samoc, M.; Luther-Davies, B. Eur. J. Inorg. Chem. 2001, 8, 2113. (c) Togni, A.; Hobi, M.; Rihs, G.; Rist, G.; Albinati, A.; Zanello, P.; Zech, D.; Keller, H. Organometallics 1994, 13, 1224. (d) Ingham, S. L.; Khan, M.; Lewis, J.; Long, N. J.; Raithby, P. R. J. Organomet. Chem. 1994, 470, 153. (e) Kasahara, A.; Izumi, T.; Shimizu, I.; Oikawa, T.; Umezawa, H.; Murakami, M.; Watanabe, 
O. Bull. Chem. Soc. Jpn. 1985, 58, 1560. (f) Shimizu, I.; Umezawa, H.; Kanno, T.; Izumi, T.; Kasahara A. Bull. Chem. Soc. Jpn. 1983, 56, 2023. (g) Shimizu, I.; Kamei, Y.; Tezuka, T.; Izumi, T. Kasahara A. Bull. Chem. Soc. Jpn. 1983, 56, 192.

15. (a) Robiette, R.; Richardson, J.; Aggarwal, V. K.; Harvey, J. N. J. Am. Chem. Soc. 2005, 127, 13468. (b) Abell, A. D.; Edmonds, M. K. In Organophosphorus Reagents, Murphy, P. J. Ed., Oxford University Press, Oxford, U.K., 2004, pp 99-127. (c) Edmonds, M.; Abell, A. In Modern Carbonyl Olefination, Takeda, T. Ed., Wiley-VCH: Weinheim, 2004, Chapter 1. (d) Mehta, G.; Chandrasekhar, J. Chem. Rev. 1999, 99, 1437. (e) Maryanoff, B. E.; Reitz, A. B. Chem. Rev. 1989, 89, 863.

16. Barlow, S.; Bunting, H. E.; Ringham, C.; Green, J. C.; Bublitz, G. U.; Boxer, S. G.; Perry, J. W.; Marder, S. R. J. Am. Chem. Soc. 1999, 121, 3715.

17. Naskar, D.; Das, S. K.; Giribabu, L.; Maiya, B. G.; Roy S. Organometallics 2000, 19, 1464. 